\title{
Role of renin-angiotensin system in adipose tissue dysfunction
}

\author{
Masaru Iwai and Masatsugu Horiuchi
}

Blockade of angiotensin II type $1\left(\mathrm{AT}_{1}\right)$ receptor improves insulin sensitivity and diabetic condition. In short-term regulation, angiotensin II changes lipid metabolism and in long-term regulation, it affects insulin sensitivity and adipocyte differentiation in adipose tissue. These effects are mainly mediated by $\mathrm{AT}_{1}$ receptor. $\mathrm{AT}_{1}$ receptor blocker improves insulin sensitivity and induces adipocyte differentiation by increasing peroxisome proliferator-activated receptor- $\gamma$ (PPAR $\gamma$ ) and transcription factors in adipose tissue in diabetic and atherosclerotic models. Clinical studies indicate that $\mathrm{AT}_{1}$ receptor blockers prevent the new onset of diabetes and improve insulin sensitivity. On the other hand, $\mathrm{AT}_{2}$ receptor stimulation appears to cause antagonistic actions against $\mathrm{AT}_{1}$ receptor signaling. Although further investigations are necessary on the $\mathrm{AT}_{2}$ receptor function in adipose tissue, studies using $\mathrm{AT}_{2}$ receptor agonists, in addition to those using $\mathrm{AT}_{1}$ receptor blockers, would contribute to the treatment of metabolic syndrome and associated pathological disorders.

Hypertension Research (2009) 32, 425-427; doi:10.1038/hr.2009.55; published online 1 May 2009

Keywords: adipocyte; angiotensin; differentiation; insulin resistance; receptor

\section{INTRODUCTION}

Renin-angiotensin system (RAS) is well known as an important regulator of blood pressure. Recent studies indicate the involvement of RAS in metabolic dysfunction. Clinical reports have shown that angiotensin II type $1\left(\mathrm{AT}_{1}\right)$ receptor blocker $(\mathrm{ARB})$ and angiotensinconverting enzyme inhibitor decrease the onset of diabetes. ${ }^{1}$ Moreover, there are recent reports that the activation of RAS induces insulin resistance through $\mathrm{AT}_{1}$ receptor-mediated signaling based on recent clinical and experimental data. ${ }^{2}$ Recently, accumulating data have been reported about the pivotal roles of angiotensin II in adipose tissue function and angiotensin II receptors. Therefore, in this review, we will summarize and discuss the roles of RAS in adipose tissue focusing on $\mathrm{AT}_{1}$ and $\mathrm{AT}_{2}$ receptors.

\section{RAS AND INSULIN RESISTANCE}

Earlier studies have shown that angiotensin II induces insulin resistance. Blockade of $\mathrm{AT}_{1}$ receptor improved oral glucose tolerance test without a significant change in plasma insulin concentration in diabetic model mice. ${ }^{3,4}$ It suggests that $\mathrm{AT}_{1}$ receptor blockade improves glucose intolerance in diabetic conditions. Similar effects were observed in other models of diabetes and glucose intolerance. ${ }^{5-7}$ This effect of $\mathrm{AT}_{1}$ receptor blockade on glucose intolerance was not caused by the change in insulin secretion. However, the glucose uptake in insulin-sensitive tissues is increased by ARBs especially in skeletal muscles. ${ }^{3}$ The increase in glucose uptake was observed in insulin- sensitive organs, such as skeletal muscle and white adipose tissue, at least partly because of the activation of the insulin-mediated IRS1/PI3/ GLUT4 cascade and the increase in blood flow. $3,4,8,9$ By contrast, we reported that in $\mathrm{AT}_{2}$ receptor null mice, glucose uptake in adipose tissues was increased. Moreover, it has been reported that ARB could protect the pancreas in type II diabetic animal model with enhanced insulin secretion. ${ }^{10}$ In the following parts, we will review mainly the roles of angiotensin II receptor subtype in adipose tissue.

\section{RAS COMPONENTS IN ADIPOSE TISSUE}

White adipose tissue acts not only as a reservoir of exceeded fuel but also as an endocrine organ secreting various bioactive factors. ${ }^{11,12}$ However, Massiéra et al. ${ }^{13}$ have reported that angiotensinogen production in adipose tissue plays an important role of RAS in whole body. Using gene-engineered mice, they indicate that adipose tissue produces angiotensinogen and it may be an important source of plasma angiotensinogen as well as the liver. The angiotensinogendeficient mice were hypotensive and showed neither detectable angiotensinogen in plasma nor morphological changes in the kidney. However, these changes observed in angiotensinogen-deficient mice were almost restored in mice, in which angiotensinogen expression is restricted to adipose tissue. ${ }^{13}$ As adipose tissues express $\mathrm{AT}_{1}$ and $\mathrm{AT}_{2}$ receptors, it is possible that RAS in adipose tissue acts as a local regulator of adipose tissue function. In our study, $\mathrm{AT}_{1}$ receptor is a major subtype, and the expression of $\mathrm{AT}_{2}$ receptor is approximately 
$1 \%$ of $\mathrm{AT}_{1}$ receptor expression in adipose tissue. ${ }^{14}$ However, it is reported that $\mathrm{AT}_{2}$ receptor expression is elevated after induction of adipocyte differentiation. ${ }^{15}$ Moreover, earlier reports suggest that $\mathrm{AT}_{2}$ receptor is, at least, expressed in adipose tissue or adipocytes with some functions. ${ }^{16}$

METABOLIC ACTION OF ANGIOTENSIN II ON ADIPOSE TISSUE Modulation of angiotensin II receptors affects plasma lipid concentration. Treatment of mice with ARB decreased the plasma level of cholesterol and free fatty acids, ${ }^{14,17}$ which is closely related with metabolic syndrome and insulin resistance.

A major type of adipose tissue in human beings is white adipose tissue. In the classical aspect of adipose tissue, white adipocytes are enlarged by the accumulation of lipids and induce obesity. In the acute phase, the lipid content in white adipose tissue is regulated by the balance of lipid synthesis and breakdown. Lipid synthesis in white adipose tissue is regulated by insulin. Lipid breakdown is regulated by humoral and neural stimulation similar to sympathetic nerve activity. Lipid breakdown in white adipose tissue also depends on the energy expenditure in the whole body.

Angiotensin II is involved in metabolic changes in adipocytes. In an earlier report, angiotensin II induced lipolysis in white adipose tissue. ${ }^{18}$ It is also reported that the mice lacking angiotensin-converting enzyme increased energy expenditure, reduced fat mass and improved glucose clearance. ${ }^{19}$ In addition, blockade of $\mathrm{AT}_{1}$ receptor increased glucose uptake in white adipose tissue. ${ }^{4}$ The modulation of insulin signaling and the regulation of oxidative stress are involved in the metabolic action of angiotensin II in adipose tissue. ${ }^{4,17}$ These effects of angiotensin II are observed in short-term (or acute) regulation of metabolism. However, the regulation of the total adipose tissue mass depends not only on acute metabolic changes but also on various other factors.

\section{ANGIOTENSIN II AND ADIPOCYTE DIFFERENTIATION}

Recent studies suggest a possible regulation of white adipose tissue mass by modulating adipocyte differentiation. ${ }^{20,21}$ Studies of action of agonist for peroxisome proliferator-activated receptor- $\gamma$ (PPAR $\gamma$ : a transcription factor) suggest that the activation of PPAR $\gamma$ induces adipocyte differentiation, thereby inducing smaller size adipocytes and increasing insulin sensitivity in white adipocytes. ${ }^{21}$ By contrast, the reduction of PPAR $\gamma$ activity suppresses adipocyte differentiation and induces enlargement of white adipocytes. Earlier studies suggest that the small-sized adipocytes increase their insulin sensitivity.

Earlier studies indicate that a blockade of the $\mathrm{AT}_{1}$ receptor enhances adipocyte differentiation. Moreover, it has been suggested that $\mathrm{AT}_{1}$ receptor blockade and $\mathrm{AT}_{2}$ receptor stimulation increases differentiation from mesenchymal stem cell in vitro. ${ }^{22}$ In our earllier report, we showed that the deficiency of $\mathrm{AT}_{1}$ a receptor, a major subclass of $\mathrm{AT}_{1}$ receptor, increased the adipocyte differentiation and the number of small-sized adipocytes in atherosclerotic model mice. ${ }^{17}$ The role of another subtype of $\mathrm{AT}_{1}$ receptor, $\mathrm{AT}_{1} \mathrm{~b}$ receptor, is totally unknown. Apolipoprotein E-deficient (ApoE-knockout $(\mathrm{KO})$ ) mice are widely used as an animal model of atherosclerosis. ApoEKO mice showed an enlargement of adipocyte size. ${ }^{17}$ In their adipose tissue, the expression of adiponectin and PPAR $\gamma$ was lower than that of wild-type mice. These changes in ApoEKO mice were recovered by the deletion of $\mathrm{AT}_{1} \mathrm{a}$ receptor $\left(\mathrm{AT}_{1} \mathrm{a} / \mathrm{ApoE}\right.$ double $\mathrm{KO}$ mice). Furuhashi et al. ${ }^{23}$ reported that an ARB, olmesartan, decreased adipocyte size without a change in the epididymal fat pads, accompanied by the improvement of insulin sensitivity in fructose-fed rats. Moreover, adiponectin is produced by adipose tissue and is involved in adipose tissue metabolism and insulin sensitivity. ${ }^{24}$ Our earlier results have indicated that the expression of adiponectin and adipocyte differentiation factors, such as $\mathrm{C} / \mathrm{EBP} \alpha$ and $\mathrm{aP} 2$, was increased in $\mathrm{AT}_{1} \mathrm{a} / \mathrm{ApoE}$ double $\mathrm{KO}$ mice or with an ARB. ${ }^{17}$

\section{ROLES OF AT 2 RECEPTOR IN ADIPOSE TISSUE DYSFUNCTION}

The expression of $\mathrm{AT}_{2}$ receptor in white adipose tissue is not abundant. Although the expression in adipose tissue seems to be low, $\mathrm{AT}_{2}$ receptor stimulation affects the adipose tissue function. It is reported that $\mathrm{AT}_{2}$ receptor-deficient mice prevented adipose tissue depletion during fasting. ${ }^{25}$ The role of $\mathrm{AT}_{2}$ receptor stimulation in adipose tissue function is still controversial. ${ }^{15}$ Administration of insulin increases glucose uptake in wild-type mice. This effect of insulin was lower in $\mathrm{AT}_{2}$ receptor $\mathrm{KO}$ mice, suggesting that the lack of $\mathrm{AT}_{2}$ receptor stimulation reduces insulin sensitivity in adipose tissue. The role of $\mathrm{AT}_{2}$ receptor stimulation in adipose tissue function is still controversial. Yvan-Charvet et al. ${ }^{16}$ reported that the deletion of the $\mathrm{AT}_{2}$ receptor reduced the adipose cell size and protected from dietinduced obesity and insulin resistance. However, in our experiment using atherosclerotic ApoEKO mice with $\mathrm{AT}_{2}$ receptor deficiency $\left(\mathrm{AT}_{2} / \mathrm{ApoE}\right.$ double $\mathrm{KO}$ mice), the lack of $\mathrm{AT}_{2}$ receptor decreased the expression of adipocyte differentiation factors, such as PPAR $\gamma, \mathrm{C} / \mathrm{EBP}$ and $\mathrm{aP} 2$, in white adipose tissue after treatment with high cholesterol diet. ${ }^{14}$ In these mice, adipocyte size and tissue mass were enlarged. In addition, plasma cholesterol and free fatty acid levels were higher in $\mathrm{AT}_{2} / \mathrm{ApoE}$ double-KO mice. In Figure 1 , we have summarized the possible roles of $\mathrm{AT}_{1}$ and $\mathrm{AT}_{2}$ receptors in adipose tissue.

\section{CLINICAL ASPECTS OF RAS IN ADIPOSE TISSUE}

It has been reported that the risk of atherosclerosis is higher in diabetic patients than in non-diabetic individuals. The metabolic syndrome is typically characterized by obesity associated with hypertension, hyperlipidemia and hyperglycemia and dysregulated adipose tissue function, and appears to be an important factor in the exaggeration of metabolic syndrome and the pathogenesis of vascular diseases. The prevention of metabolic syndrome becomes highlighted in the field of diabetes and cardiovascular medicine.

Recent clinical studies have shown that ARBs prevent the new onset of diabetes and improve insulin sensitivity. ${ }^{1,2,26,27}$ The results of

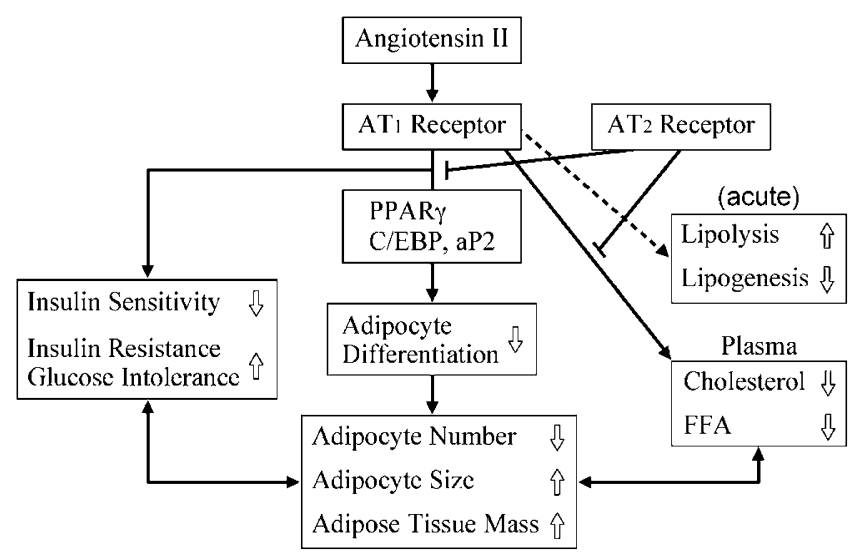

Figure 1 Roles of $\mathrm{AT}_{1}$ and $\mathrm{AT}_{2}$ receptors in adipose tissue function. In adipose tissue, $\mathrm{AT}_{1}$ receptor stimulation in the short-term modulates lipid metabolism; however, in the long term, it affects the adipocyte differentiation, insulin resistance and plasma lipid level. $\mathrm{AT}_{2}$ receptor stimulation appears to antagonize the action of $\mathrm{AT}_{1}$ receptor-mediated signaling. Abbreviation: FFA, free fatty acid. 
clinical studies also suggest that blockade of the $\mathrm{AT}_{1}$ receptor decreases events related to atherosclerosis. ${ }^{28,29}$ These results support the notion that $\mathrm{AT}_{1}$ receptor stimulation is pivotal in the pathogenesis of the metabolic syndrome and associated vascular lesion formation. Moreover, the studies on the roles of $\mathrm{AT}_{2}$ receptor suggest that $\mathrm{AT}_{2}$ receptor agonists, such as compound 21, could be useful and would contribute to the treatment of metabolic syndrome and associated pathological disorders. ${ }^{30}$

\section{CONFLICT OF INTEREST}

The authors declare no conflict of interest.

1 Elliott WJ, Meyer PM. Incident diabetes in clinical trials of antihypertensive drugs: a network meta-analysis. Lancet 2007; 369: 201-207.

2 Dzau V. The cardiovascular continuum and renin-angiotensin-aldosterone system blockade. J Hypertens Supp/ 2005; 23: S9-S17.

3 Shiuchi T, Iwai M, Li H-S, Wu L, Min L-J, Li J-M, Okumura M, Cui T-X, Horiuchi M. Angiotensin II type 1 receptor blocker, valsartan, enhances insulin sensitivity in skeletal muscles of diabetic mice. Hypertension 2004; 43: 1003-1010.

4 Iwai M, Chen R, Imura Y, Horiuchi M. TAK-536, a new $\mathrm{AT}_{1}$ receptor blocker, improves glucose intolerance and adipocyte differentiation. Am J Hypertens 2007; 20: 579-586.

5 Shao J, Iwashita N, Ikeda F, Ogihara T, Uchida T, Shimizu T, Uchino $H$, Hirose $T$, Kawamori R, Watada $\mathrm{H}$. Beneficial effects of candesartan, an angiotensin II type 1 receptor blocker, on beta-cell function and morphology in $\mathrm{db} / \mathrm{db}$ mice. Biochem Biophys Res Commun 2006; 344: 1224-1233.

6 Wei Y, Sowers JR, Clark SE, Li W, Ferrario CM, Stump CS. Angiotensin II-induced skeletal muscle insulin resistance mediated by NF- $\mathrm{KB}$ activation via NADPH oxidase. Am J Physiol Endocrinol Metab 2008; 294: E345-E351.

7 Henriksen EJ. Improvement of insulin sensitivity by antagonism of the renin-angiotensin system. Am J Physiol Regul Integr Comp Physiol 2007; 293: R974-R980.

8 Kirwan JP, del Aguila LF. Insulin signalling, exercise and cellular integrity. Biochem Soc Trans 2003; 31: 1281-1285.

9 Goossens GH, McQuaid SE, Dennis AL, van Baak MA, Blaak EE, Frayn KN, Saris WH, Karpe F. Angiotensin II: a major regulator of subcutaneous adipose tissue blood flow in humans. J Physiol 2006; 571: 451-460.

10 Shao J, Iwashita N, Ikeda F, Ogihara T, Uchida T, Shimizu T, Uchino $H$, Hirose $T$, Kawamori R, Watada $\mathrm{H}$. Beneficial effects of candesartan, an angiotensin II type 1 receptor blocker, on beta-cell function and morphology in $\mathrm{db} / \mathrm{db}$ mice. Biochem Biophys Res Commun 2006; 344: 1224-1233.

11 Sharma AM, Staels B. Review: peroxisome proliferator-activated receptor gamma and adipose tissue - understanding obesity-related changes in regulation of lipid and glucose metabolism. J Clin Endocrinol Metab 2007; 92: 386-395.

12 Ahima RS. Adipose tissue as an endocrine organ. Obesity (Silver Spring) 2006; 14(Suppl 5): 242S-249S

13 Massiéra F, Bloch-Faure M, Ceiler D, Murakami K, Fukamizu A, Gasc JM, QuignardBoulange A, Negrel R, Ailhaud G, Seydoux J, Meneton P, Teboul M. Adipose angio- tensinogen is involved in adipose tissue growth and blood pressure regulation. FASEB J 2001; 15: 2727-2729.

14 Iwai M, Tomono Y, Inaba S, Kanno H, Senba I, Mogi M, Horiuchi M. AT2 receptor deficiency attenuates adipocyte differentiation and decreases adipocyte number in atherosclerotic mice. Am J Hypertens 2009 (in press).

15 Schling P. Expression of angiotensin II receptors type 1 and type 2 in human preadipose cells during differentiation. Horm Metab Res 2002; 34: 709-715.

16 Yvan-Charvet L, Even P, Bloch-Faure M, Guerre-Millo M, Moustaid-Moussa N, Ferre P, Quignard-Boulange $A$. Deletion of the angiotensin type 2 receptor $\left(A T_{2} R\right)$ reduces adipose cell size and protects from diet-induced obesity and insulin resistance. Diabetes 2005; 54: 991-999.

17 Tomono $\mathrm{Y}$, Iwai M, Inaba S, Mogi M, Horiuchi M. Blockade of $\mathrm{AT}_{1}$ receptor improves adipocyte differentiation in atherosclerotic and diabetic models. Am J Hypertens 2008; 21: 206-212.

18 Cabassi A, Coghi P, Govoni P, Barouhiel E, Speroni E, Cavazzini S, Cantoni AM, Scandroglio R, Fiaccadori E. Sympathetic modulation by carvedilol and losartan reduces angiotensin II-mediated lipolysis in subcutaneous and visceral fat. J Clin Endocrinol Metab 2005; 90: 2888-2897.

19 Jayasooriya AP, Mathai ML, Walker LL, Begg DP, Denton DA, Cameron-Smith D, Egan GF, McKinley MJ, Rodger PD, Sinclair AJ, Wark JD, Weisinger HS, Jois M, Weisinger RS. Mice lacking angiotensin-converting enzyme have increased energy expenditure, with reduced fat mass and improved glucose clearance. Proc Natl Acad Sci USA 2008; 105: 6531-6536.

20 Sharma AM, Janke J, Gorzelniak K, Engeli S, Luft FC. Angiotensin blockade prevents type 2 diabetes by formation of fat cells. Hypertension 2002; 40: 609-611.

21 Tsuchida A, Yamauchi T, Kadowaki T. Nuclear receptors as targets for drug development: molecular mechanisms for regulation of obesity and insulin resistance by peroxisome proliferator-activated receptor gamma, CREB-binding protein, and adiponectin. J Pharmacol Sci 2005; 97: 164-170.

22 Matsushita K, Wu Y, Okamoto Y, Pratt RE, Dzau VJ. Local renin angiotensin expression regulates human mesenchymal stem cell differentiation to adipocytes. Hypertension 2006; 48: 1095-1102

23 Furuhashi M, Ura N, Takizawa H, Yoshida D, Moniwa N, Murakami H, Higashiura K, Shimamoto K. Blockade of the renin-angiotensin system decreases adipocyte size with improvement in insulin sensitivity. J Hypertens 2004; 22: 1977-1982.

24 Kadowaki T, Yamauchi T. Adiponectin and adiponectin receptors. Endocrine Reviews 2005; 26: 439-451.

25 Yvan-Charvet L, Even P, Lamandé N, Ferré P, Quignard-Boulangé A. Prevention of adipose tissue depletion during food deprivation in angiotensin type 2 receptordeficient mice. Endocrinology 2006; 147: 5078-5086.

26 Weir MR. Effects of renin-angiotensin system inhibition on end-organ protection: can we do better? Clin Ther 2007; 29: 1803-1824.

27 Kintscher U, Foryst-Ludwig A, Unger T. Inhibiting angiotensin type 1 receptors as a target for diabetes. Expert Opin Ther Targets 2008; 12: 1257-1263.

28 Dzau VJ. Tissue angiotensin and pathobiology of vascular disease: a unifying hypothesis. Hypertension 2001; 37: 1047-1052.

29 Daugherty A, Cassis L. Angiotensin II-mediated development of vascular diseases. Trends Cardiovasc Med 2004; 14: 117-120.

30 Kaschina E, Grzesiak A, Li J, Foryst-Ludwig A, Timm M, Rompe F, Sommerfeld M, Kemnitz UR, Curato C, Namsolleck P, Tschöpe C, Hallberg A, Alterman M, Hucko T, Paetsch I, Dietrich T, Schnackenburg B, Graf K, Dahlöf B, Kintscher U, Unger T, Steckelings UM. Angiotensin II type 2 receptor stimulation: a novel option of therapeutic interference with the renin-angiotensin system in myocardial infarction? Circulation 2008; 118: 2523-2532. 